\title{
THELODUS ADMIRABILIS N. SP. (AGNATHA) FROM THE UPPER SILURIAN OF THE EAST BALTIC
}

Among the Upper Ludlovian - Lower Downtonian thelodonts of the Thelodus sculptilis Zone (see Mяpcc, 1982) there occurs a new species of the genus Thelodus. This species, T. admirabilis is related to T. sculptilis described by W. Gross (1967) from the Upper Ludlovian bone-bed of Ramsåsa, Skåne, Sweden. However, its scales are more complicated in ornamentation, and the stratigraphical distribution of the species is more limited. The material collected from two outcrops and 12 borings (including samples of V. Karatajūtè-Talimaa from 2 Lithuanian borings) shows that $T$. admirabilis always appears above the base of the $T$. sculptilis Zone and does not reach the base of the succeeding Nostolepis gracilis Zone.

Outside the Baltic area, $T$. admirabilis has been found in an erratic boulder 0.410 , Mochty, Warsaw Province, though described under two different names - Thelodus schmidti (Pander) and Trimerolepis lithuanica Kar.-Tal. (see Halstead, Turner, 1970). V. Karatajūtè-Talimaa (Kapaтаюте-Талимаa, 1978, p. 114) noted the presence of Thelodus scales with a complicated pattern in the Upper Silurian of the East Baltic but assigned them to the head scales of $T$. sculptilis.

The scales are subjected to variations in shape and ornamentation of the crown in different parts of the squamation (Мярсc, in press). The samples include oral, cephalo-pectoral, postpectoral, precaudal and pinnal (?) scales. The terminology of thelodont scales is given according to W. Gross (1967), L. B. Halstead, S. Turner (1970, etc.), V. KaratajūtéTalimaa (Каратаюте-Талимаa, 1978) and T. Märss (Мярсc, in press).

The specimens with indexes $\mathrm{Pi}$ are housed at the Institute of Geology, Academy of Sciences of the Estonian SSR.

I thank Dr. E. Kurik for her advice and assistance.

SEM micrographs were made at the same institute by $U$. Paap and V. Klimov, the other photographs by U. Veske, thin sections by U. Kestlane and the author. I am indebted to the colleagues indicated for their kind help.

Family Coelolepidae Pander, 1856

Genus Thelodus Agassiz, 1839

Thelodus admirabilis $\mathrm{n} . \mathrm{sp}$.

P1. I, II, III, IV.

Derivation of name admirabilis: admirable.

1970. Thelodus schmidti (Pander) - Halstead, Turner, p. 335, Pl. 1, Fig. 1, Text-Fig. 1.

1970. Trimerolepis lithuanica Karatajūtè-Talimaa - Halstead, Turner, p. 337, Pl.. 1, Figs 2, 3, Text-Figs 2, 3. 


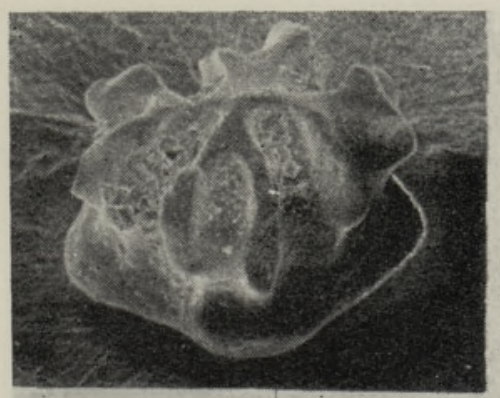

1
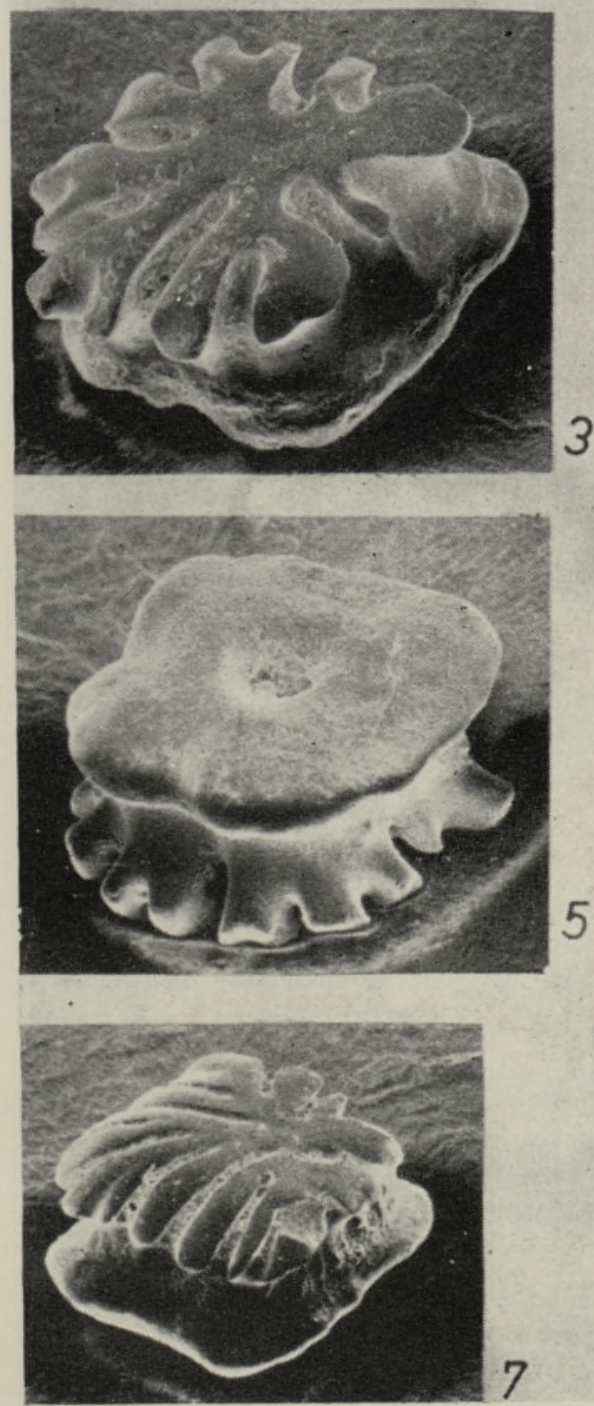
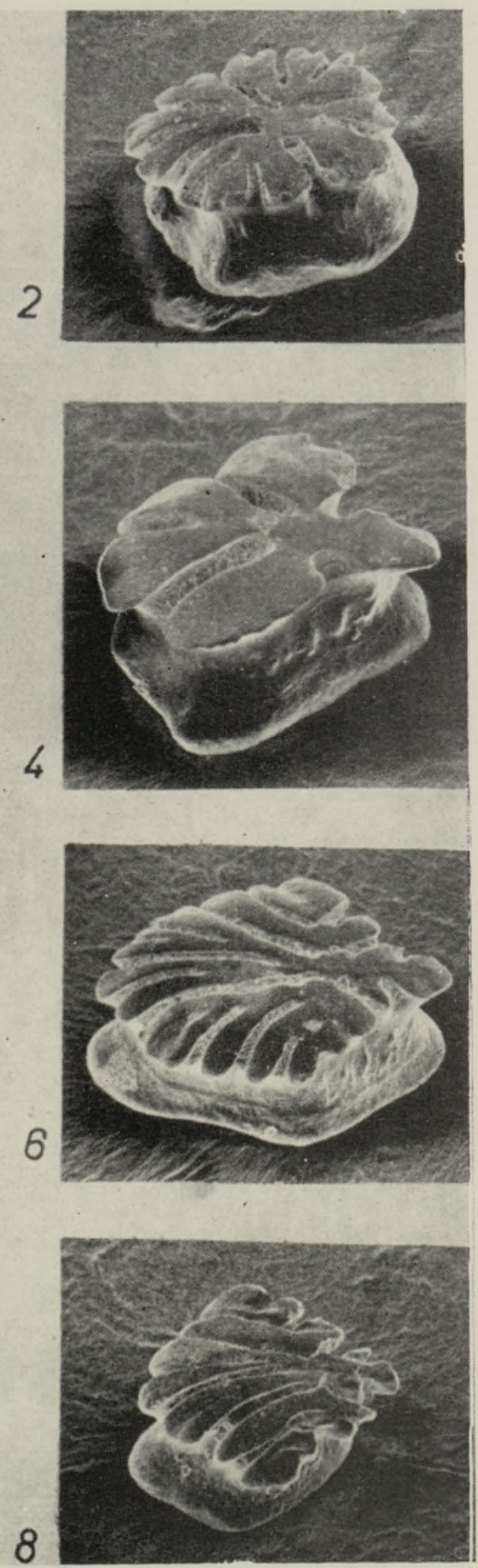

Thelodus admirabilis n. sp. SEM micrographs of the scales: 1, 2 - oral scales; 3-7 - cephalo-pectoral scales; 8 - scale transitional between cephalo-pectoral and postpectoral ones.

1 - Pi 6509, $2-\mathrm{Pi} 6500,3-\mathrm{Pi} 6492,4-\mathrm{Pi} 6488,5-\mathrm{Pi} 6493,6$ - hol ot y pe, Pi 6505, 7 - Pi 6502, 8-Pi 6501, Sakla boring, depth $6.2 \mathrm{~m}$, Kuressaare Stage, approximately $\times 80$. 


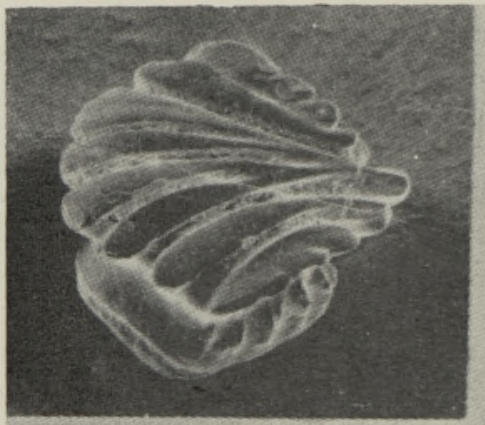

1
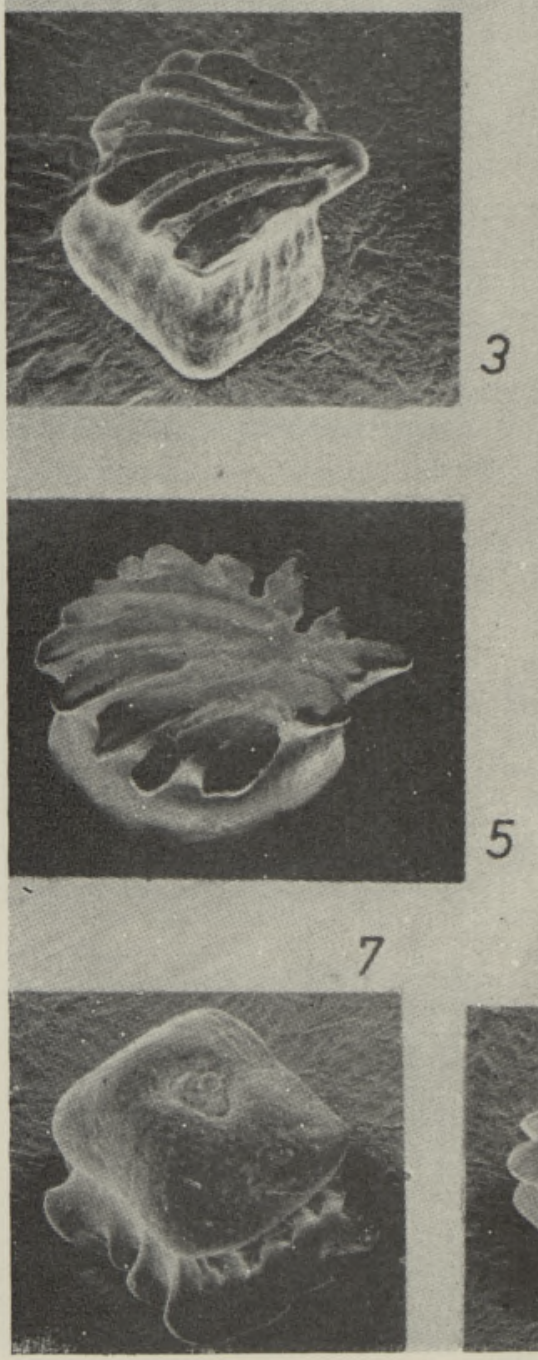

5

Thelodus admirabilis n. sp. SEM micrographs of the scales: $1,2,4$ - postpectoral scales; 3 - precaudal scale; $5,6,7$ - precaudal (?) scales; 8 - small scale from the posterior part of the body; 9 - pinnal(?) scale.

$1-\mathrm{Pi} 6499,2-\mathrm{Pi} 6506,3-\mathrm{Pi} 6503,4-\mathrm{Pi} 6507,5-\mathrm{Pi} 6495,6-\mathrm{Pi} 6496$, 7 - Pi 6508, 8 - Pi 6490, 9 - Pi 6497, Sakla boring, depth 6,2 $\mathrm{m}$ (6-Ohesaare boring, depth $83.10 \mathrm{~m})$, Kuressaare Stage, approximately $\times 80$. 


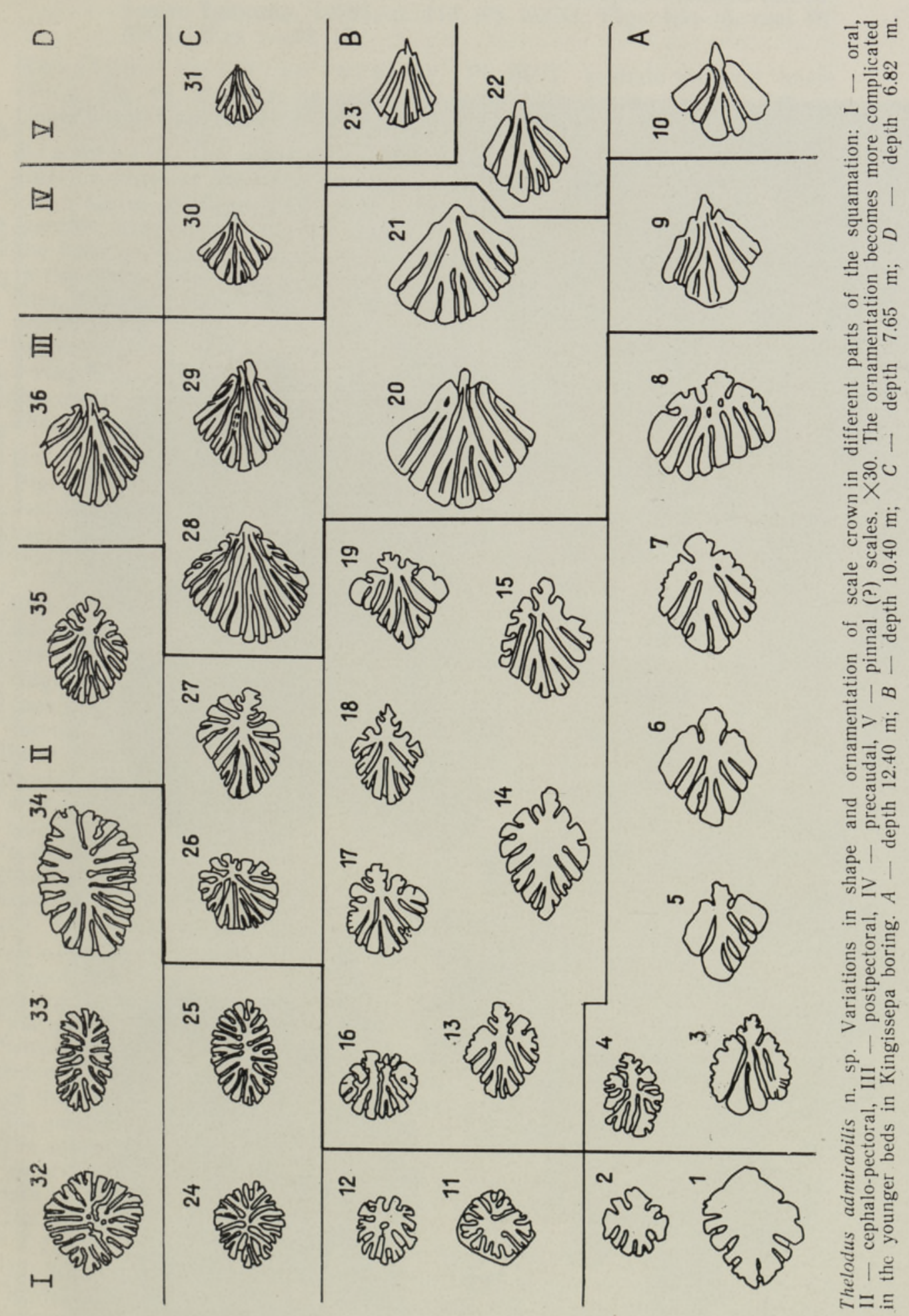




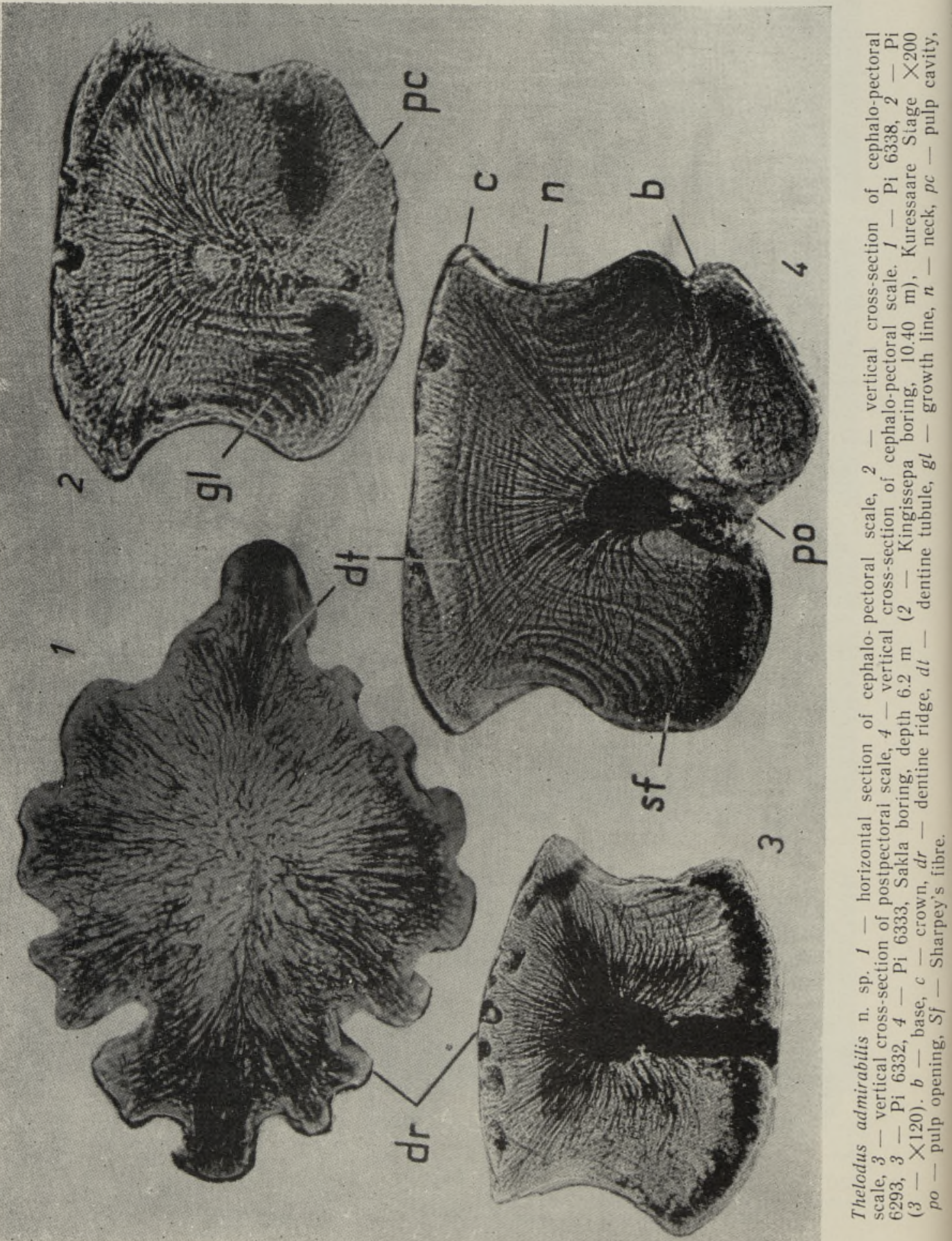


1978. Thelodus sculptilis Gross, partim - Karatajūtè-Talimaa (Kapaтаюте-Талимаa, 1978), p. 113, Pl. XXXI, Figs 13-16, non Pl. XXXI, Figs $1-12,17$.

Holotype and type locality. Pi 6505, cephalo-pectoral scale (P1. I, Fig. 6), Estonia, Saaremaa Island, Sakla boring, depth $6.2 \mathrm{~m}$, Upper Ludlovian, Kuressaare Stage, Tahula Beds.

$\mathrm{D}$ i a $\mathrm{g} \mathrm{n}$ os is. Thelodont with medium scales, with convex or flat crown, anterior edges of the latter downturned. The ornamentation of the crowns has a series of ridges that tend to be lobulated, represented by steep furrows directed towards the centre of the scales on the anterior part of the body or longitudinal on the scales of the posterior part of the body. In the distal part of the scale the medial lobe is separated from the lateral ones by deep notches. The ridges are two or three times the width of the furrows. The neck is high, distinct, with small, stepped ridges in the posterio-lateral part. The base is almost as wide as the crown, forming a ring with bead-like swellings around the pulp opening. The latter is in the centre of the base. The histological structure of the scales is of Thelodus parvidens type (see description).

De s cription. Morphology. The crown outline of the oral scales (Pl. I, Figs 1, 2; Pl. III, Figs 1, 2, 11, 12, 24, 25, 32, 33, 34) is rounded to oval, surface convex to flat. The numerous dentine ridges converge and narrow towards the centre of the crown. They tend to bifurcate at the outer margin, being separated by steep deep furrows.

The cephalo-pectoral scales (P1. I, Figs 3-7; P1. II, Fig. 8(?); P1. III, Figs $3-7,8(?), 13-19,26,27,35)$ have flat crowns with downturned anterior edges. The often bisected dentine ridges converge near the posterior corner of the scale. The shallow but steep grooves between the ridges die out in the same direction or proceed through the scale. In this case only a narrow dentine ridge along the axis occurs, and the posteriolateral ridges are shorter. Posterior corners of the cephalo-pectoral scales have always almost circular or pointed peg-like posterior projections. Scales (PI. I, Fig. 8; Pl. III, Fig. 8) have relatively long dentine ridges anteriorly and a segmented margin posteriorly. The arrangement of the ridges of these specimens suggests that they come from the region of the body, where the squamation of the cephalo-pectoral region grades into that of the postpectoral one. The quadrangular or diamond-shape plate surface of postpectoral scales (Pl. II, Figs 1, 2; P1. III, Figs 9, 20, 21, 28, 29,36 ) is flat with downwards curved anterior edges, possessing sharp striation of numerous (up to 9) dentine ridges and furrows. The dentine ridges are occasionally divided by a shallow groove, which fades out along the length of the ridge. Some furrows $(2-5)$ open on the posterior margin of the crown and the central ones form a pointed peg-like projection which slightly extends beyond the base. Two specimens (Pl. II, Figs 5, 6) have ridges converging near the posterior corner. Posterio-lateral ridges of the crown are divided and form free spines, which project upward over the posterior edges. The base has a forward pointed spur. The position of the scales on the body of Thelodus described above is not known. However, according to dimensions, ornamentation and the forward-pointed spur, it can be supposed that they come from the precaudal part of the body behind the dorsal or anal fin.

Ornamentation of the precaudal scales (Pl. II, Fig. 3; Pl. III, Figs 10, 22,30 ) is similar to postpectoral ones: there are longitudinal about $5-6$ dentine ridges, from which the central one ends with a peg-like posterior projection extending beyond the base. The dentine ridges are less bifurcated. The scales are smaller. Pinnal (?) scales (Pl. II, Fig. 9; PI. III, Figs 23,31 ) have relatively longer and narrower crowns with about four 
dentine ridges. The posterior lobe may be lacking. In a scale (Pl. II, Fig. 8) the bifurcated dentine ridges converge on the posterior half of the crown as on cephalo-pectoral scales. The mid keel, however, shows that the scale was placed posteriorly. The neck of the scales (Pl. I, Figs 4, 6; Pl. II, Figs $1-9)$ is distinct, high, smooth anterio-laterally and with $4-8$ vertical stepped ridges in the posterio-lateral part. The base (Pl. I, Fig. 5; Pl. II, Figs 4,7 ) of adult specimens is of medium size, slightly expanding (Pl. II, Fig. 4) in the centre of the scale with bead-like swellings (Pl. I, Fig. 5) or a forward-pointed spur (Pl. II, Fig. 6). Pulp opening is in the centre of the base.

Measurements of the scales (in $\mathrm{mm}$ )

\begin{tabular}{l|c|c|c|c|c}
\hline \multirow{2}{*}{ Number of scale } & \multicolumn{2}{|c|}{ Length of } & \multicolumn{2}{|c|}{ Width of } & \multirow{2}{*}{ Maximum height } \\
\cline { 2 - 3 } & crown & base & crown & base & \\
\hline Pi 6748 (oral) & 0.35 & 0.32 & 0.36 & 0.32 & 0.28 \\
Pi 5516 (cephalo-pectoral) & 0.62 & 0.62 & 0.46 & 0.43 & 0.31 \\
Pi 5511 (postpectoral) & 0.64 & 0.58 & 0.74 & 0.67 & 0.49 \\
Pi 5508 (precaudal) & 0.52 & 0.42 & 0.41 & 0.36 & 0.35 \\
Pi 6752 (pinnal?) & 0.43 & 0.32 & $0.3 \mathrm{i}$ & 0.36 & 0.27
\end{tabular}

Histology. The dentine tubules radiate from the single pulp cavity towards the crown surface (Pl. IV, Figs 1-4). The straight dentine tubules in the centre of the crown are shorter than those rising in the direction of the margins. The dentine tubules branch at several levels. On the neck the dentine tubules are sinuous and sparser. On the base they can interflow with Sharpey's fibres (Pl. VI, Fig. 4).

$\mathrm{C}$ o m paris on. There are similarities between the species of Phlebolepis, Katoporus, Logania and Thelodus in the general shape and ornamentation of oral, cephalo-pectoral, postpectoral, precaudal and pinnal scales. Oral scales are rounded or oval with radial type of ornamentation on the crown. Cephalo-pectoral scales, as a rule, have large, oval, oakleaf-like crowns with short ridges and grooves on the anterio-lateral edges. Most of the species have a flat and smooth orown surface $(P h l$. elegans and species of genera Katoporus and Logania). In some species (Phlebolepis ornata, Thelodus traquairi) smooth cephalo-pectoral scales are unknown. Neither can it be stated with certainty whether smooth scales from the Kuressaare and Kaugatuma Stages belong to Thelodus parvidens only or also to $T$. sculptilis and T. admirabilis n. sp. The postpectoral scales have diamond-shaped crowns with numerous dentine ridges (Phlebolepis, some species of Logania, Thelodus) or posterio-lateral spines (most species of Logania) or crown with several spines projecting over its posterior margins (Katoporus tricavus). The bases have, as a rule, a short anterior spur (Phlebolepis, Katoporus, most of Logania species). Precaudal scales narrow, number of dentine ridges on the crown decreases, mid keel becomes more distinct (in case it is present), furrows are relatively deeper. Species of Logania and Thelodus have «trilobatus»-type scales with fine, longitudinal ridges, which project over the posterior end as short spines, and anterior spur at the base. Pinnal scales are carinal, narrow and short.

The ornamentation of the scales of Thelodus admirabilis n. sp. has distinct features, considerably differing from those of other Thelodus species. The numerous dentine ridges and steep furrows between them and a pointed peg-like posterior projection characterize $T$. admirabilis. Thelodus laevis has also steep furrows on the crown, but they are not so numerous, the pointed peg-like posterior projection is lacking. The crowns of scales 
of $T$. marginatus have a downstepped lateral rim and gentle longitudinal (except oral scales) dentine ridges in the central part of the crown. Histologically T. marginatus and T. laevis differ from T. admirabilis n. sp. in having curved dentine tubules. Most of the crowns of the scales of $T$. sculptilis are anteriorly bifurcated. The furrows are not steep. The crowns have a pointed peg-like posterior projection as in many scales of T. admirabilis $\mathrm{n}$. sp. The character of the squamation of $T$. parvidens is not yet very clear. It seems that the greater part of the body was covered with scales having flat crowns. The scales of $T$. traquairi known so far are horn-like, dentine ridges, often bifurcated and with small stepped ridges on the vertical crown surface. The scales of this shape grade into scales with an elongated horizontal posterior part. Horn-like scales are not known in $T$. admirabilis $\mathrm{n}$. sp.

F a cial distribution. T. admirabilis n. sp. has been found in the deposits of lagoon, shoal, open-shelf and slope belts of the Silurian Palaeobaltic basin.

Occurrence. Upper Ludlovian to Lower Downtonian of Estonia (Kuressaare Stage and Aigu Beds of Kaugatuma Stage), Latvia and Lithuania (upper part of the Pagėgiai and lower part of the Minija Formation); Downtonian (erratic boulder) from Warsaw Province.

Referred material and localities. Several hundred wellpreserved scattered $T$. admirabilis scales from borings: Kingissepa (depth 6.82-12.45), Sakla (6.2-8.07), Tahula-709 (4.7), Kihnu-526 (86.8), Kaugatuma $(13.40-42.25)$, Ohesaare $(73.60-83.10)$, Sõrve-514 (130.8130.9), Estonia; Kolka-54 (242.0-279.9), Ventspils (390.8-418.5), Pavilosta (604.4-648.6), Latvia; Sutkai-86 (727.7), Jurbarkas (1040.2$1047.9 \mathrm{~m}$ ), Lithuania (personal communication by V. KaratajūtèTalimaa).

Outcrops: Kudjape ditch, temporary outcrops in the town of Kingissepa, Estonia.

Associated agnathans and fish. Katoporus tricavus, Logania cuneata, Thelodus parvidens, T. sculptilis, T. traquairi, Cyathaspidinae (Archegonaspis ?) sp., Cephalaspidida gen. et sp. ind., Anaspida gen. et sp. A., Nostolepis striata, Gomphonchus sandelensis, Poracanthodes porosus or Gomphonchus hoppei.

por

\section{REFERENCES}

Gross, W. Uber Thelodontier-Schuppen. - Palaeontogr., A127, 1967, 1-2, 1-67.

$\mathrm{Halstead}$ L., Turner, S. Thelodonts from Upper Silurian erratic boulder 0.410 . - Proc. Geol. Soc. (London), 1970, 1660, 335-340.

К а р а т ю те - Т ал и м а В. Н. Телодонты силура и девона СССР и Шпицбергена. Вильнюс, 1978.

М ярс с Т. Биозоны позвоночных (Силур Прибалтики), - В кн.: Сообщества и биозоны в силуре Прибалтики. Таллин, 1982.

M я р с Т. Чешуйный покров Phlebolepis. - В кн.: Рыбы Среднего Палеозоя. (В печати.)

Academy of Sciences of the Estonian SSR, Institute of Geology 
Tiiu MARSS

\section{OLEMSILURI THELODUS ADMIRABILIS N. SP. (AGNATHA) IDA-BALTIKUMIS}

Artiklis on kirjeldatud perekonna Thelodus uut liiki T. admirabilis, mida on leitud Eesti, Läti ja Leedu ülemladlou ja alamdauntoni kihtidest ning Poola rändpangastest.

Tuйy MЯPCC

\section{THELODUS ADMIRABILIS N. SP. (AGNATHA) ИЗ ВЕРХНЕГО СИЛУРА ВОСТОЧНОИ ПРИБАЛТИКИ}

Для нового вида характерна сложная скульптура кроны чешуй. Орнамент состоит из многочисленных дентиновых ребрышек (до 9), разделенных резкими узкими бороздами. Последние могут быть продольными, направленными в центр кроны или в сторону задней половины ее. На задней медиальной части кроны многих чешуй выделяется зубец, расположенный между более глубокими выемками. Описанный новый вид найден в отложениях верхнего лудлова и нижнего даунтона Әстонии, Латвии, Литвы и в валунах окрестности Варшавы. 